\title{
Creation of Investment Funds in Ukraine by Individuals as a Criterion for Sustainable Development of the Country's Economy
}

\author{
By Illia Morhachov ${ }^{1}$, Ievgen Ovcharenko ${ }^{1}$, Yevgen Ivchenko ${ }^{1}$, Maxym Buchniev , \\ Nataliia Tkachenko ${ }^{1}$, Nataliia Derzhak ${ }^{1}$
}

\begin{abstract}
The article substantiates the hypothesis that the creation of investment funds by individuals in the country can be considered as a criterion for the existence of conditions of sustainable development of its economy. By example of Ukraine clarifies the issue of creating investment funds by individuals, in particular in terms of motives, feasibility, economic feasibility, problems and ways to solve the latter. For the conditions of Ukraine as an important factor in the feasibility of creating an investment fund by an individual identified the possibility of ensuring the transfer of inheritance to the heirs under national law. The stages of creation and development of the studied subjects are identified, which can be considered as "pain points" when considering the conditions of sustainable development in the country. The absence of facts of crossing these points in Ukraine by the studied subjects indicates the lack of conditions for sustainable development in the country. The refusal of the share form at the stage of existence of the limited liability company is substantiated, as well as the need to combine investment activities with others that are not capital-intensive given the high level of complexity and capital intensity of the researched business.
\end{abstract}

Keywords: sustainability development, criterion of sustainable development, investment fund, stock market, stocks, bonds, financial leverage, alternative pension provision, inheritance.

\section{Introduction}

Many things are done by ordinary people, including the creation of investment funds. There are many such funds in the world and they are all, of course, created by humans, not natural phenomena. However, in most cases (almost 99\%) the founders of such structures are legal entities, mainly financial institutions with significant financial capabilities. The capital-intensive nature of the processes of creating investment funds, at first glance, generally excludes the possibility of their creation by individuals. On the other hand, examples of successful stories of creation of investment funds, where the founders were individuals, allow us to draw attention to the feasibility of such practices.

The relevance of research on the problems and feasibility of creating investment funds by individuals is also due to the need to create in developing countries additional opportunities for the development of alternative pensions. Ukraine is no of exception. In our work, we will also pay attention to the motives of individuals to create their own investment funds, because it is the motives that are a prerequisite for the initial steps in any activity. Thus, the disclosure of the problems of the article lies in such a quadrilateral (Fig. 1). 
${ }^{1}$ Volodymyr Dahl East Ukrainian National University, Ukraine, Severodonetsk

MOTIVES

EXPEDIENCY

\section{Creation of Investment Funds by Individuals}

\section{ECONOMIC FEASIBILITY}

\section{PROBLEMS}

Fig. 1. Quadrangle of issues of creating an investment fund by an individual

As mentioned earlier, the creation of investment funds in the country is a rare phenomenon given the existence of objective economic constraints. Therefore, the facts of creation (or lack thereof) can be considered as a criterion for the existence of conditions for sustainable development of the economy.

\section{Analysis of recent research and publications}

The study of publications on the subject of work [1-9] allows us to recognize the existence of deep developments in the institutionalization of investment processes, including regional ones. The following scientists have contributed to the development of the theory of sustainable development of investment processes: Buzko I.R, Vartanova O.V, Galgash R.A, Dyachenko Yu.Yu., Klyus Yu.I., Semenenko I.M. At the same time, the issue of creating investment funds by individuals is poorly understood and has reserves for deepening in terms of considering the facts of the establishment of such entities as criteria for the availability of conditions for sustainable development in the economy.

\section{The aim of the study}

The aim of the work is to substantiate the hypothesis that the creation of investment funds by individuals in the country can be considered as a criterion for the existence of conditions of sustainable development of its economy.

\section{Research methods}

Comparisons and modeling are used as the main research methods in the article. Using the comparison, we compared the conditions and facts of creation of investment funds in Ukraine with the country - a conditional standard. The United States was used as a conditional standard of a country with favorable conditions for sustainable economic development. It is in the United States that the creation of investment funds is common, including the creation by individuals, for example, we considered the Warren Buffett Foundation "Berkshire Hathaway". It was assumed that the objective economic factors of 
fund creation in the countries are the same (for example, capital-intensive nature), but country - in each country specific.

Under the conditions in Ukraine, we simulated the situation of creating an investment fund by an individual. Thus the problems which the corresponding founder will face were considered, the directions of the decision of these problems were offered. The purpose of this modeling was to determine the "pain points" in the stages of creation and development of the studied subjects. The facts of the intersection of these points indicate the existence of conditions for sustainable development in the country.

\section{Results}

Consider in more detail the following components of the creation of investment funds in Ukraine:

\section{Motives}

As a motive for creating an investment fund for an individual can be recognized as the desire to form a long-term commercial profitable system - a participant in investment processes, ie the creation and improvement of a successful business that can later be sold or inherited.

As a rule, a certain business is created by specialists in a certain business when they transform this business into a more highly organized form. For example, they move from the category of private entrepreneurs to a legal entity. At the same time, a limited liability company is created in the first steps, and later - a public joint stock company. Of course, not all types of business move to highly organized forms of business (public joint stock companies). If we consider investment funds, then as potential founders should be considered persons who have long been are investors and have gained significant experience in investment processes.

Individuals can invest as individual investors without creating legal entities. Therefore, even with a high level of motivation, the question of expediency arises.

\section{Expediency}

For an individual, the expediency of creating their own investment fund at first is to ensure the transfer of inheritance to the heirs under national law.

The current conditions of investment processes, in particular for most developing countries, are that often the residence of the investor and the broker do not match. Currently, most individual investors are interested in the US stock market, while they may be citizens of other countries. In this case, the purchase of securities on the US stock market requires in most cases cooperation with foreign brokers. This raises the problem of inheritance transfer in the event of the investor's death. Under the conditions of creation of a legal entity, such a problem is solved by translating the problem of inheritance into national legislation.

Such a problem, and, accordingly, the means of its solution become more relevant when the amount of investment of an individual investor is significant. The larger such volumes, the greater the level of expediency of creating a legal entity to ensure the reliability of inheritance transfer.

Secondly, it is also expedient to expand the scope of activities and generate income from the use of not only equity, but also borrowed capital. For a legal entity compared to an 
individual, there are greater opportunities to use borrowed capital, use the effect of financial leverage and expand the scope of activities. However, as noted in our previous works $[10,11]$, such an effect can be obtained by issuing bonds, while an ordinary limited liability company is deprived of such an opportunity. Therefore, it is necessary to transform the business to the level of a public joint stock company.

Economic Feasibility

Since individual investors do not have the opportunity to issue their own bonds, it is necessary to create a legal entity to obtain the effect of financial leverage. The effect of financial leverage is almost the only economic factor (reason) why an individual investor can move to the category of a legal entity (if we do not take into account the factor of security of inheritance). Issuance of own bonds is the cheapest source of borrowed capital. Other alternatives allow only for speculative activity, which mainly leads to losses.

Problems

Having motives, expediency and economic substantiation of creation of investment fund the individual investor in this way faces many problems, however the most essential of them is scale of activity. This scale of activity should cover overhead costs. That is, the problem is rather overhead costs, the size of which determines the break-even point. Overheads are present in every business, but the creation of an investment fund is a capital-intensive business, so the break-even point in this case depends on the amount of capital invested.

Therefore, when creating an investment fund by an individual, an important issue will be to reach a break-even point, which will be determined by the overhead costs of such a structure. Moreover, the creation of the fund can be step-by-step and include two main steps:

1) creation of the fund as a limited liability company;

2) creation of a fund as a public joint-stock company.

At each of these steps, the level of overhead will be significantly different. At the stage of existence of the fund as a limited liability company, accounting can be carried out independently by the founder without the involvement of a separate accountant. Similarly, you can limit yourself without office space. Therefore, the amount of overhead costs is reduced to zero.

The founder may stop at this step if the purpose is only to solve the problem of inheritance in national law. In addition, the transfer of inheritance between individuals usually leads to the completion of those investment processes that were initiated by the deceased investor. Translating these processes into the form of a legal entity will allow even after the death of individuals (founders) not to interrupt the course of investment processes.

But for further development and use of the effect of financial leverage, it is necessary to increase the scale and gradually move to the form of a public joint stock company. Therefore, overheads will arise, so they need to be planned and covered. Let's try to estimate the minimum level of such costs under the conditions of Ukraine (table 1).

Table 1

Estimation of the size of overhead costs of the investment fund at the first stages of creation it in Ukraine

\begin{tabular}{|l|l|}
\hline Overhead item & Amount, USD month \\
\hline Salary of the head & 500,00 \\
\hline
\end{tabular}




\begin{tabular}{|l|l|}
\hline Accountant's salary & 450,00 \\
\hline Wage taxes $(22 \%)$ & 210,00 \\
\hline Office rental & 500,00 \\
\hline Other overheads & 100,00 \\
\hline Sum & 1760,0 \\
\hline
\end{tabular}

According to table 1, the annual overhead costs can be about 21 thousand US dollars. If we take into account that the amount of overhead costs should be in the range of $0.5-1 \%$ of the capital under management, the amount of such capital should be more than 2 million US dollars. For an individual, this is a lot of money, so you need to look for ways to neutralize overhead costs.

Note: the well-known investment fund Vanguard S\&P 500 ETF (VOO) has an overhead of $0.15 \%$ of the fund's capital. This is one of the minimum values for investment funds. In addition, the IPO will include the cost of the audit and other activities related to the work of the stock exchange.

As a way to neutralize the problem of overhead costs when establishing an investment fund, an individual is to combine the activities of such a fund with other activities. At the same time, part of the overhead costs is redistributed to the that activities. Important: if the investment activity is capital-intensive but with a low level of labor intensity, then the related activities of the fund should be the opposite - labor-intensive, but with a low level of capital intensity. In addition, such varieties activities must be in condition to be initiated by an individual.

For example, the such characteristics correspond to the varieties of activities: a) publishing and editorial activities; b) educational activities in terms of training, counseling; c) engineering activities, in particular in terms of development of design estimates, technical supervision, consulting; d) advocacy, legal advice; e) provision of accounting and auditing services.

Thus, for an individual - the founder of an investment fund, it is logical to gradually create it according to an approximate scheme (Table 2).

Table 2: The expediently sequence of creation of an investment fund by an individual under the conditions of Ukraine

\begin{tabular}{|l|l|l|}
\hline Stage & List of works & Remarks \\
\hline $\begin{array}{l}\text { 1. Opening by an } \\
\text { individual } \\
\text { investor of his } \\
\text { own brokerage } \\
\text { account and the } \\
\text { beginning of } \\
\text { investment } \\
\text { activity }\end{array}$ & $\begin{array}{l}\text { Opening a brokerage account. Creating } \\
\text { your own portfolio of shares. } \\
\text { Increasing the stock portfolio. }\end{array}$ & $\begin{array}{l}\text { Gaining experience in investment activities } \\
\text { in the stock market. Creating your own } \\
\text { "airbag". Ideally, at this step, the future } \\
\text { founder should form a reliable source of } \\
\text { passive income for those years when the } \\
\text { investment fund is not yet profitable. If the } \\
\text { investor was successful in this step, you can } \\
\text { of a legal entity - a on to the second. }\end{array}$ \\
$\begin{array}{l}\text { company } \\
\text { move on the }\end{array}$ & $\begin{array}{l}\text { Establishment of a limited liability } \\
\text { company. Drawing up of the charter } \\
\text { and constituent documents providing } \\
\text { both investment activity at own means, } \\
\text { and other not capital-intensive kinds of } \\
\text { activity. Concluding an agreement with } \\
\text { a brokerage organization. Formation of }\end{array}$ & $\begin{array}{l}\text { At this stage, the source of investment } \\
\text { activity is the founder's own funds. } \\
\text { At this stage, it is important to create } \\
\text { organizational and legal conditions for } \\
\text { investment activities, as it will be the main } \\
\text { in the future. }\end{array}$ \\
\hline
\end{tabular}




\begin{tabular}{|c|c|c|}
\hline Stage & List of works & Remarks \\
\hline & $\begin{array}{l}\text { the initial diversified portfolio of } \\
\text { securities, consisting of shares of } \\
\text { leading global companies. }\end{array}$ & $\begin{array}{l}\text { It is important to identify and neutralize the } \\
\text { first possible problems that may arise with } \\
\text { the tax authorities while the founder } \\
\text { operates with small amounts of capital*. } \\
\text { This stage is training and testing. At this } \\
\text { stage, accounting can be carried out } \\
\text { without the involvement of a third-party } \\
\text { accountant, as well as without the use of } \\
\text { the office, which reduces overhead to zero. } \\
\text { If this step was successfully completed, you } \\
\text { can proceed to the next. }\end{array}$ \\
\hline $\begin{array}{l}\text { 3. Beginning of } \\
\text { additional } \\
\text { varieties of } \\
\text { activities }\end{array}$ & $\begin{array}{l}\text { Increasing the authorized capital and } \\
\text { assets in the form of a diversified } \\
\text { portfolio of shares of global } \\
\text { corporations. } \\
\text { Selection of related activities and } \\
\text { development of documentation for } \\
\text { obtaining licenses. } \\
\text { Obtaining licenses for related activities } \\
\text { and planning their start. }\end{array}$ & $\begin{array}{l}\text { At this stage, it is advisable to form the } \\
\text { authorized capital at the expense of one } \\
\text { founder, as this fund must be constantly } \\
\text { increased, while the assets created at its } \\
\text { expense are constantly changing in price. } \\
\text { The stage will be successful if was } \\
\text { neutralized emerging problems and } \\
\text { obtained licenses for related activities. }\end{array}$ \\
\hline $\begin{array}{l}\text { 4. Sustainable } \\
\text { business } \\
\text { development }\end{array}$ & $\begin{array}{l}\text { Continuation of increasing the } \\
\text { authorized capital and assets in the } \\
\text { form of a diversified portfolio of shares } \\
\text { of global corporations. } \\
\text { Beginning of additional varieties } \\
\text { activities. } \\
\text { Increase in overhead costs. }\end{array}$ & $\begin{array}{l}\text { With the start of related activities, the } \\
\text { amount of work of accounting will increase } \\
\text { (it may be necessary to involve an } \\
\text { accountant), there will be a need for office } \\
\text { space. At this step, overhead costs will } \\
\text { increase, it is important that the lion's share } \\
\text { of them be covered by related activities } \\
\text { without compromising the gradual growth } \\
\text { of assets. At this stage, it is possible to stop } \\
\text { in the long run, but it will be impossible to } \\
\text { obtain the effect of financial leverage and } \\
\text { significant scaling of activities. } * * \\
\text { When the income from related activities } \\
\text { will already cover both current overhead } \\
\text { costs and overhead costs in the transition } \\
\text { to the form of a public joint stock } \\
\text { company, it is possible to move to the next } \\
\text { stage. }\end{array}$ \\
\hline $\begin{array}{l}\text { 5. Establishment } \\
\text { of a public joint } \\
\text { stock company }\end{array}$ & $\begin{array}{l}\text { Transformation of a limited liability } \\
\text { company into a public joint stock } \\
\text { company. } \\
\text { Processing and reissuance of founding } \\
\text { documents. } \\
\text { The purpose of this step is to enter the } \\
\text { national stock exchange. } \\
\text { Conducting an advertising campaign. }\end{array}$ & $\begin{array}{l}\text { At this stage, the complexity of accounting } \\
\text { will increase significantly, as will the other } \\
\text { overhead costs, for example, to involve } \\
\text { auditors. } \\
\text { There is a need to promote and advertise } \\
\text { the established business. } \\
\text { It is assumed that the fund's shares on the } \\
\text { secondary stock market will be bought by } \\
\text { individuals - citizens of the country, so the } \\
\text { mission of the fund should be positioned } \\
\text { as an alternative pension. }\end{array}$ \\
\hline $\begin{array}{l}\text { 6. Organization } \\
\text { of IPO }\end{array}$ & $\begin{array}{l}\text { Issue of shares on the national stock } \\
\text { exchange. } \\
\text { Investing received funds in shares of } \\
\text { global corporations. }\end{array}$ & $\begin{array}{l}\text { It is desirable that the volume of the issue } \\
\text { of shares does not exceed } 50 \% \text { of the } \\
\text { authorized capital to prevent loss of } \\
\text { control over the fund. }\end{array}$ \\
\hline
\end{tabular}




\begin{tabular}{|c|c|c|}
\hline Stage & List of works & Remarks \\
\hline & $\begin{array}{l}\text { The stock portfolio that will be formed } \\
\text { at this stage and already formed at the } \\
\text { previous ones will become the } \\
\text { foundation of the pyramid in the } \\
\text { future, on which the superstructure will } \\
\text { develop: bond issue and subsequent } \\
\text { IPOs, so it will take some time (one to } \\
\text { three years) to proceed to the next step. } \\
\text { Formation of efficiency statistics of the } \\
\text { formed stock portfolio. }\end{array}$ & $\begin{array}{l}\text { Successful organization of IPOs, even with } \\
\text { increasing overhead costs, will allow you to } \\
\text { focus on investment activities and make it } \\
\text { the main type. } \\
\text { The issue of own shares will allow to scale } \\
\text { the business, reduce the specific overhead } \\
\text { costs, but does not allow to get the effect } \\
\text { of the use of financial leverage. } \\
\text { When the efficiency (return) of the fund's } \\
\text { assets in the long run consistently exceeds } \\
\text { the interest rate on bonds, you can move } \\
\text { on to the next step. }\end{array}$ \\
\hline $\begin{array}{l}\text { 7. Issue of own } \\
\text { bonds }\end{array}$ & $\begin{array}{l}\text { Bond issue on the national stock } \\
\text { exchange. }\end{array}$ & $\begin{array}{l}\text { This step will both increase the scale of the } \\
\text { business (without losing control of the } \\
\text { business) and reduce the specific overhead } \\
\text { costs, and get the effect of financial } \\
\text { leverage. } \\
\text { This step is a kind of top in the business of } \\
\text { creating investment funds for individuals. }\end{array}$ \\
\hline $\begin{array}{l}\text { 8. Formation of a } \\
\text { full-fledged } \\
\text { investment fund }\end{array}$ & $\begin{array}{l}\text { Further issues of own shares and bonds } \\
\text { on the national stock exchange. } \\
\text { Further increase of assets in shares of } \\
\text { world companies. } \\
\text { Diversification of brokerage accounts. } \\
\text { Organization of a system PR-company: } \\
\text { creation and development of own } \\
\text { YouTube-channel, site. }\end{array}$ & $\begin{array}{l}\text { Expansion of activities and further growth } \\
\text { of overhead costs. } \\
\text { Activation of the PR-company will involve } \\
\text { IT specialists, purchase of own server, } \\
\text { equipment. }\end{array}$ \\
\hline
\end{tabular}

\section{Comments:}

* 1) at the stage of establishing the fund, the problem may be the view and position of employees of tax authorities to calculate the profit not on the fact of sale of assets, but on the fact of growth of their book value;

2) when working with a foreign broker, there may be additional requirements to the founding documents or requirements for the minimum amount of funds.

** 1) at the stage of existence of a limited liability company the increase of the authorized capital is possible only at the own expense of the founder or his immediate relatives. Attracting third-party investors is problematic due to the difficulties of registration of entry-exit and revaluation of the share in the authorized capital. Because of this, the share form of organization of a limited liability company in practice is a failure.

As we can see from Table 2, the creation of an investment fund for an individual is a systematic and purposeful set of many "small" steps that must be taken to achieve this goal. In addition, the transition from the previous stage to the next for an individual can take many years. In this case, such a long way is justified, because the main purpose of the transition from the category of individual investor to legal entity is to ensure the security of inheritance and neutralize the cessation of investment processes at the time of death of such an investor. Thus, the idea of creating an investment fund by an individual can be implemented in practice in several generations.

According to Table 2, the transition from the 1st stage to the 2 nd, from the 4 th to the 5 th, as well as the 6th and 7th stages should be considered as "pain points" of creation of an investment fund by an individual both in Ukraine and other countries.

When countries have the conditions for sustainable development, the number of individual investors increases over time. The number of successful and professional 
individual investors is growing. As the number of such investors increases, some of them cross the 2nd stage and become founders of investment funds. When the relevant conditions in the country are favorable, some of these entities reach the 5th stage. In turn, the 6th and 7 th stages are a logical continuation of the 5 th.

In Ukraine in the 2000s it was mutual funds, including individuals, that were created in the wake of the excitement (and the creation of the stock market in the country in general) and the arrival of foreign investors on the Ukrainian stock market. The objects for investment for such entities were securities listed on the national stock exchange. None of these investment funds reached the 5th and subsequent stages. In addition, almost all such funds collapsed due to the lack of sustainable development of the national stock market. When foreign investors left the Ukrainian stock market in 2008, securities lost significantly in price, and investors (unit holders) suffered losses and withdrew en masse from such investment funds.

If we do not even mention 2008-2009 (which are a crisis for the whole financial world), then in general the Ukrainian stock market is not characterized by steady growth, as evidenced by the dynamics of its stock index (Fig. 2). As we can see from the figure, the sharp fall in stock prices and the lack of sustainable growth in Ukraine is a common phenomenon.

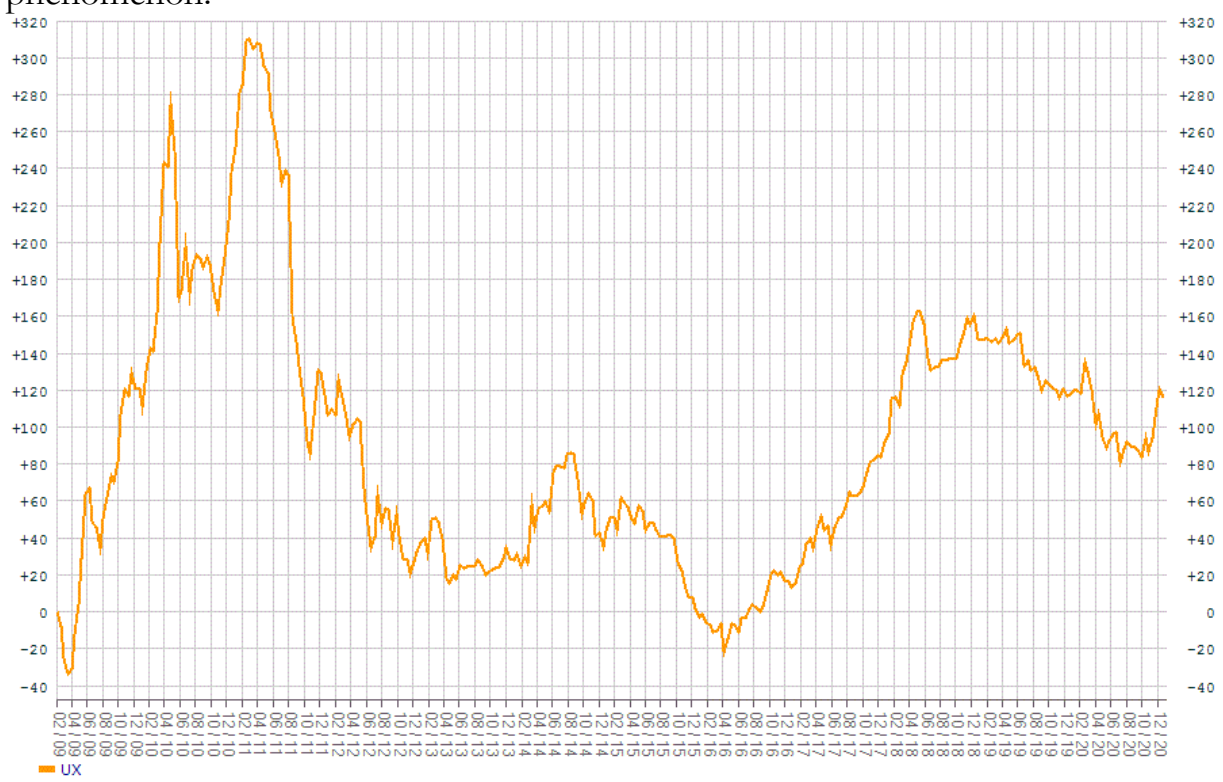

Fig.2. Dynamics of the Ukrainian stock index UX

Since in Ukraine none of the studied investment funds reached the 5th stage, and most of the mutual funds were liquidated due to losses, the economic conditions in the country can not be characterized as favorable for sustainable development. In particular, mutual investment funds in Ukraine have proved to be an unviable form of investment business organization. Currently, the United States is dominated by ETFs, and investment funds in general, whose shares are freely traded on the stock exchange. 
Refusal from a mutual of forms of investment funds at the stage of existence of a limited liability company either requires a relatively large amount of equity from the founderindividual (which is an exception for an individual), or combination with other activities.

\section{Conclusions}

Investment funds organized as mutual companies have shown their failure both in Ukraine and in other countries. For individuals - individual investors operating in Ukraine, the reasons, expediency and motives for the transition to the stage of existence of a legal entity were identified. In this case, the abandonment of the share form at the stage of existence of a limited liability company and the high level of complexity and capital intensity necessitate the combination of investment activities with others that are not capital-intensive.

Based on the modeling, the list of the main problems that the organizer of the researched business will face in the conditions of Ukraine was specified, however in the long run such problems are not critical and can be neutralized. The high level of capital intensity of the researched business both in the conditions of Ukraine and other countries determines the single and exclusive nature of the emergence of investment funds, which are created by individuals. However, such isolated facts testify to the existence of conditions for sustainable economic development.

The absence of facts in Ukraine of investment funds reaching the level of a public jointstock company (including those where the founders are individuals) indicates that the conditions for sustainable economic development have not yet been formed. The lack of conditions for the development of investment funds in Ukraine also worsens the conditions for the development of alternative pensions in the presence of acute demand for the latter in the country.

\section{References}

Buzko, I.R. Vartanova, O.V. \& Golubenko, G.O. (2002) Stratehichne upravlinnya investytsiyamy ta innovatsiyna diyal'nist' pidpryyemstva [Strategic investment management and innovation of the enterprise], Volodymyr Dahl East Ukrainian National University, Luhansk. (in Ukrainian)

Semenenko I.M. (2017) Zabezpechennya staloho rozvytku rehionu: instytutsiyni zasady ta transformatsiya tsil'ovoho upravlinnya pidpryyemstvamy [Ensuring sustainable development of the region: institutional principles and transformation of target management of enterprises], Volodymyr Dahl East Ukrainian National University, Severodonetsk. (in Ukrainian)

Semenenko I., Halhash R. \& Sieriebriak K. (2019) Sustainable development of regions in Ukraine: before and after the beginning of the conflict. Equilibrium. Quarterly Journal of Economics and Economic Policy. Vol. 14, Issue 2. P. 317-339. DOI: https://doi.org/10.24136/eq.2019.015

Halhash R., Semenenko I., Ovcharenko I. \& Borova G. (2020) Innovative forms of realization of regional social policy by organizing public dialogue and communication in conditions of post-conflict transformation in Eastern Ukraine. European Journal of Sustainable Development. Vol. 9, No 2. P. 391-404. DOI: https://doi.org/10.14207/ejsd.2020.v9n2p391

Klyus Y.I. (2019) Innovatsiynyy rozvytok pidpryyemstv rehionu na pidstavi na pidstavi strukturnykh zrushen' vnaslidok postkonfliktnoyi transformatsiyi [nnovative development of enterprises in the region on the basis of structural changes due to post-conflict transformation]. Bulletin of the Volodymyr Dahl East Ukrainian National University. Vol 4, no 252. pp. 48 - 53. (in Ukrainian) 
Buzko I.R., Dyachenko Yu. Yu. \& Nemashkalo O.A. (2015) Instytutsiyni reformy ta orhanizatsiynoekonomichni mekhanizmy rehulyuvannya rehional'noho rozvytku $\mathrm{v}$ umovakh yevropeys'koyi intehratsiyi [Institutional reforms and organizational and economic mechanisms of regulation of regional development in the conditions of European integration], Bulletin of Kremenchuk Mykhailo Ostrohradsky National University. Issue 4. pp. 123 - 128. (in Ukrainian)

Nenkov N., Petrova M., Dyachenko Y. Bondarenko G. \& Pustovit V. (2017) Intelligent and Cognitive Technologies in Education of International Economic Relations Students and Human Resource Development: Methodology in Language Teaching and Distance Learning. European Journal of Sustainable Development. Vol. 6, No. 4, pp. 353-360. DOI: https://doi.org/10.14207/ejsd.2017.v6n4p353

Morhachov I., Koreniev E., Chorna O. \& Khrystenko L. (2019) Regional Regulation of Investment Activity in Developing Countries: Example of Ukraine, Management Theory and Studies for Rural Business and Infrastructure Development. Vol. 41. No. 2: 168-182. DOI: https://doi.org/10.15544/mts.2019.15

Morhachov Illia \& Ovcharenko Ievgen (2020) Prerequisites for Successful Regulation of Regional Investment Processes. Management Theory and Studies for Rural Business and Infrastructure Development. Vol. 42. No. 3: 289-294. DOI: https://doi.org/10.15544/mts.2020.28

Ovcharenko R.V., Morhachov I.V., Ovcharenko Ie.I \& Ivchenko Ie. A. (2020) Peredumovy stvorennya ta rehulyuvannya rehional'nykh investytsiynykh fondiv [Prerequisites for the creation and regulation of regional investment funds]. Public administration: improvement and development. vol. 10. (in Ukrainian) DOI: 10.32702/2307-2156-2020.10.37

Rudyashko A.I., Ovcharenko Ie.I, Zos-Kior M.V. \& Morhachov I.V. (2020) Pryntsypy finansovoyi stiykosti investytsiynykh fondiv [Principles of financial stability of investment funds]. Business Inform. vol. 10. P. 301 - 306. (in Ukrainian) DOI: https://doi.org/10.32983/2222-4459-2020-10-301-306 